\title{
The Utilization of Sulfur, Sulfenyl, Selenenyl, and Seleninyl Chlorides in the Conversion of Aldoximes to Nitriles
}

\author{
George Sosnovsky and James A. Krogh \\ Department of Chemistry, University of Wisconsin-Milwaukee, Milwaukee, Wisconsin 53201, USA
}

Z. Naturforsch. 34b, 511-515 (1979); received November 28, 1978

Sulfur Chlorides and Disulfides, Conversion of Aldehydes to Nitriles, Selenium Chlorides and Diselenides, Nitriles, Aldoximes

\begin{abstract}
The comparative usefulness of six sulfur, sulfenyl, selenenyl, and seleninyl chlorides towards aldoximes in the presence of a base were examined under similar reaction conditions. The reactions of aromatic aldoximes with either sulfur dichloride (1), sulfur monochloride (2), or trichloromethane sulfenyl chloride (3) in either ether or chloroform at $23-35{ }^{\circ} \mathrm{C}$ after one hour resulted in $60-84 \%$ yields of nitriles. Under the same conditions, the reactions of aliphatic aldoximes with either 1, 2, or $\mathbf{3}$ gave mixtures of products, while at -40 to $-30^{\circ} \mathrm{C}, 15-22 \%$ yields of aliphatic nitriles were obtained. The reactions of aliphatic and aromatic oximes with either benzenesulfenyl chloride (4), benzeneselenenyl chloride (5), or benzeneseleninyl chloride $(\mathbf{6})$ produced after fifteen minutes to three hours the corresponding nitriles in $71-96 \%$ yields at $23-35{ }^{\circ} \mathrm{C}$.
\end{abstract}

In recent years a variety of reagents have been considered for the transformation of aldoximes to nitriles [1]. Due to deficiencies in some respects, such as, low yields, expensive or not readily available reagents, harsh reaction conditions, or, perhaps, most importantly, a lack of generality for both aliphatic and aromatic aldoximes, the search for mild, generally applicable methods continues. Recently, we reported [1-3] two such methods, using selenium dioxide in chloroform [1], and phosphorus imidazolides [2-3]. In connection with this work we have also investigated the scope and limitations of a number of readily accessible sulfur and selenium chlorides in the conversion of aldoximes to nitriles.

In the literature one finds only a few reports on the use of chlorinated sulfur compounds in the transformation of aldoximes to nitriles. Thus, thionyl chloride was used successfully in only one case to produce 3-cyanoindole from the corresponding aldoxime [4]. The reactions of arylsulfonyl chlorides with substituted aromatic aldoximes resulted in mixtures of nitriles and isonitriles [5]. The reaction of para-chlorophenyl chlorothioformate [6] gave high yields of aromatic nitriles. Chlorosulfonium salts [7], and phenylchlorosulfite [8] appear to be generally applicable, but are not readily available.

Requests for reprints should be sent to Professor Dr. G. Sosnovsky, Department of Chemistry, University of Wisconsin-Milwaukee, Milwaukee, Wisconsin 53201, USA.

$0340-5087 / 79 / 0300-0511 / \$ 01.00 / 0$
Now we would like to report on a series of transformations of aldoximes to nitriles using other readily accessible sulfur and selenium reagents. These reactions provide in some cases, attractive options to the existing methods.

The results of our work are summarized in Schemes 1 and 2, and Tables I and II. The reactions with the readily available reagents, sulfur dichloride (1), and sulfur monochloride (2), allow for the conversion of two moles of aldoxime per mole of reagent.

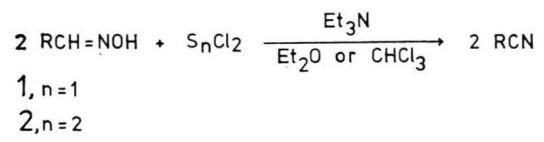

The reactions are achieved in the presence of triethylamine and are exothermic. The progress of these reactions is monitored by thin layer chromatography. The reaction of aromatic aldoximes with either $\mathbf{1}$ or $\mathbf{2}$ is complete in one hour to give nitriles in $78-86 \%$ yields. Surprisingly, this method under the same reaction conditions, was inappliacable to aliphatic aldoximes, and no trace of nitriles or any other well defined product could be isolated, in spite of the fact that nearly quantitative yields of triethylamine hydrochloride were obtained. Nevertheless, at the lower reaction temperatures of -40 to $-30{ }^{\circ} \mathrm{C}$, aliphatic nitriles can be isolated in $15-19 \%$ yields (Table I).

The reaction of trichloromethanesulfenyl chloride (3), with aromatic aldoximes proceeds in analogy to the sulfur chlorides 1 and 2 and results in $60-62 \%$ yields of aromatic nitriles and $26-30 \%$ yields of 
Table I. Preparation of nitriles from aldoximes and reagents $\mathbf{1}$ and $\mathbf{2}$.

\begin{tabular}{|c|c|c|c|c|c|c|c|c|c|}
\hline $\begin{array}{l}\mathrm{RCH}=\mathrm{NOH} \\
\mathrm{R}\end{array}$ & $\begin{array}{l}\text { Rea- } \\
\text { gent }\end{array}$ & $\begin{array}{l}\text { Yield } \\
{[\%]^{\mathrm{a}}} \\
\text { of } \\
\text { nitrile }\end{array}$ & $\begin{array}{l}\text { Solvent }{ }^{\mathrm{b}} \\
\text { Reaction } \\
\text { time } \\
{[\mathrm{h}]}\end{array}$ & $\begin{array}{l}\text { m.p. or b.p./ } \\
\text { torr (Lit. } \\
\text { m.p. or b.p./ } \\
\text { torr) [12] }\end{array}$ & $\begin{array}{l}n_{\mathrm{D}}^{25} \\
{\left[\text { Lit. } n_{\mathrm{D}}\right.} \\
\text { (temp)] [13] }\end{array}$ & $\begin{array}{l}\text { Molec- } \\
\text { ular } \\
\text { formula }^{c}\end{array}$ & $\begin{array}{l}\text { Mol. } \\
\text { weight } \\
\text { found }\end{array}$ & $\begin{array}{l}\text { IR } \\
\text { (neat or } \\
\text { nujol) } \\
\gamma_{\max }\left[\mathrm{cm}^{-1}\right]\end{array}$ & $\begin{array}{l}{ }^{1} \mathrm{H}-\mathrm{NMR} \\
(\mathrm{CDCl}) \\
\delta[\mathrm{ppm}]\end{array}$ \\
\hline \multirow[t]{2}{*}{ Phenyl } & 1 & 84 & $\begin{array}{l}\text { Ether } \\
(0.5)\end{array}$ & $\begin{array}{l}69-70^{\circ} / 10 \\
\left(69^{\circ} / 10\right)\end{array}$ & $\begin{array}{l}1.5275 \\
{\left[1.5289\left(20^{\circ}\right)\right]}\end{array}$ & $\begin{array}{l}\mathrm{C}_{7} \mathrm{H}_{5} \mathrm{~N} \\
(103.12)\end{array}$ & 101 & 2230 & $7.2-7.7(\mathrm{~m})$ \\
\hline & 2 & 78 & $\begin{array}{l}\text { Ether } \\
(0.5)\end{array}$ & $\begin{array}{l}70-71 \% 10 \\
\left(69^{\circ} / 10\right)\end{array}$ & $\begin{array}{l}1.5269 \\
{\left[1.5289\left(20^{\circ}\right)\right]}\end{array}$ & $\begin{array}{l}\mathrm{C}_{7} \mathrm{H}_{5} \mathrm{~N} \\
(103.12)\end{array}$ & 99 & 2230 & $7.2-7.7(\mathrm{~m})$ \\
\hline \multirow[t]{2}{*}{$\begin{array}{l}\text { 4-Methoxy- } \\
\text { phenyl }\end{array}$} & 1 & 86 & $\begin{array}{l}\text { Ether } \\
(0.5)\end{array}$ & $\begin{array}{l}60^{\circ} \\
\left(61-62^{\circ}\right)\end{array}$ & & $\begin{array}{l}\mathrm{C}_{8} \mathrm{H}_{7} \mathrm{NO} \\
(133.15)\end{array}$ & 128 & 2225 & $\begin{array}{l}3.7-3.9(\mathrm{~s}, 3 \mathrm{H}) ; \\
6.75-7.55(\mathrm{~m}, 4 \mathrm{H})\end{array}$ \\
\hline & 2 & 79 & $\begin{array}{l}\text { Ether } \\
(0.5)\end{array}$ & $\begin{array}{c}59-60^{\circ} \\
\left(61-62^{\circ}\right)\end{array}$ & & $\begin{array}{l}\mathrm{C}_{8} \mathrm{H}_{7} \mathrm{NO} \\
(133.15)\end{array}$ & 127 & 2225 & $\begin{array}{l}3.7-3.9(\mathrm{~s}, 3 \mathrm{H}) ; \\
6.75-7.55(\mathrm{~m}, 4 \mathrm{H})\end{array}$ \\
\hline \multirow[t]{2}{*}{$n$-Propyl } & 1 & 15 & $\begin{array}{l}\text { Chloro- } \\
\text { form } \\
(1.0)\end{array}$ & $\begin{array}{c}115^{\circ} / 750 \\
\left(117^{\circ} / 760\right)\end{array}$ & $\begin{array}{l}1.3851 \\
{\left[1.3842\left(20^{\circ}\right)\right]}\end{array}$ & $\begin{array}{l}\mathrm{C}_{4} \mathrm{H}_{7} \mathrm{~N} \\
(69.11)\end{array}$ & 68 & 2250 & $\begin{array}{l}0.9-1.1(\mathrm{t}, 3 \mathrm{H}) ; \\
1.40-2.0(\mathrm{~m}, 2 \mathrm{H}) \\
2.2-2.5(\mathrm{t}, 2 \mathrm{H})\end{array}$ \\
\hline & 2 & 17 & $\begin{array}{l}\text { Chloro- } \\
\text { form } \\
(1.0)\end{array}$ & $\begin{array}{c}116^{\circ} / 750 \\
\left(117^{\circ} / 760\right)\end{array}$ & $\begin{array}{l}1.3849 \\
{\left[1.3842\left(20^{\circ}\right)\right]}\end{array}$ & $\begin{array}{l}\mathrm{C}_{4} \mathrm{H}_{7} \mathrm{~N} \\
(69.11)\end{array}$ & 66 & 2250 & $\begin{array}{l}0.9-1.1(\mathrm{t}, 3 \mathrm{H}) ; \\
1.40-2.0(\mathrm{~m}, 2 \mathrm{H}) \\
2.2-2.5(\mathrm{t}, 2 \mathrm{H})\end{array}$ \\
\hline \multirow[t]{2}{*}{$n$-Hexyl } & 1 & 19 & $\begin{array}{l}\text { Chloro- } \\
\text { form } \\
(1.0)\end{array}$ & $\begin{array}{c}68^{\circ} / 11 \\
\left(183^{\circ} / 760\right)\end{array}$ & $\begin{array}{l}1.4110 \\
{\left[1.4104\left(30^{\circ}\right)\right]}\end{array}$ & $\begin{array}{l}\mathrm{C}_{7} \mathrm{H}_{13} \mathrm{~N} \\
(111.18)\end{array}$ & 108 & 2235 & $\begin{array}{l}0.75-1.1(\mathrm{t}, 3 \mathrm{H}) \\
1.2-2.0(\mathrm{~m}, 8 \mathrm{H}) \\
2.1-2.6(\mathrm{~m}, 2 \mathrm{H})\end{array}$ \\
\hline & 2 & 18 & $\begin{array}{l}\text { Chloro- } \\
\text { form } \\
(1.0)\end{array}$ & $\begin{array}{c}67^{\circ} / 10 \\
\left(183^{\circ} / 760\right)\end{array}$ & $\begin{array}{l}1.4111 \\
{\left[1.404\left(30^{\circ}\right)\right]}\end{array}$ & $\begin{array}{l}\mathrm{C}_{7} \mathrm{H}_{13} \mathrm{~N} \\
(111.18)\end{array}$ & 106 & 2235 & $\begin{array}{l}0.75-1.1(\mathrm{t}, 3 \mathrm{H}) ; \\
1.2-2.0(\mathrm{~m}, 8 \mathrm{H}) ; \\
2.1-2.6\end{array}$ \\
\hline
\end{tabular}

a Yield of pure isolated products.

b Temperature of reaction: for $\mathrm{R}=\operatorname{aryl}, 23-35^{\circ}$; for $\mathrm{R}=\operatorname{alkyl}-40$ to $-30{ }^{\circ} \mathrm{C}$.

c The microanalyses for all aromatic nitriles were in satisfactory agreement with the calculated values $\mathrm{C}, \pm 0.30 ; \mathrm{H}, \pm 0.30 ; \mathrm{N}, \pm 0.30$.

aliphatic nitriles. The workup of the reaction mixture is somewhat complicated by the formation of by-products and sulfur residues.

Compounds 4, 5, and 6 provide the most universally applicable reagents in this series for the conversion of aldoximes to nitriles. Benzenesulfenyl chloride (4) is readily prepared by the chlorination of thiophenol [9], and is stable for several days when stored under nitrogen. Benzeneselenenyl chloride (5) is a stable crystalline solid which is commercially available. Benzeneseleninyl chloride $(6)$ is readily prepared by the oxidation of $\mathbf{5}$ with ozone [10]. A solution of $\mathbf{6}$ in methylene chloride remains stable in a refrigerator at $-20{ }^{\circ} \mathrm{C}$ for several weeks.

$$
\begin{aligned}
& \mathrm{RCH}=\mathrm{NOH}+\mathrm{R}^{\prime} \mathrm{Cl} \underset{\mathrm{Et}_{2} \mathrm{O} \text { or } \mathrm{CHCl}_{3} \mathrm{~N}}{\longrightarrow} \mathrm{RCN}+ \\
& \text { 3, } \mathrm{R}^{\prime}=\mathrm{Cl}_{3} \mathrm{CS}- \\
& 4, R^{\prime}=O-S_{-} \\
& 5, \mathrm{R}^{\prime}=\mathrm{O}-\mathrm{Se}- \\
& 6, R^{\prime}=0 \text { - } \mathrm{Se}^{\mathrm{O}}
\end{aligned}
$$

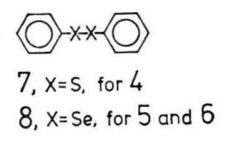

The reaction of compounds 4,5 , and $\mathbf{6}$ with both aliphatic and aromatic aldoximes proceeds readily at room temperature to give $71-96 \%$ yields of the corresponding nitriles (Table II). While the reaction with aromatic aldoximes is completed in about fifteen minutes, the reaction with aliphatic aldoximes requires three hours to give $74-83 \%$ yields of the corresponding nitriles. An interesting feature of these reactions is the formation of diphenyldisulfide (7) from the reaction with benzenesulfenyl chloride (4) and diphenyldiselenide (8) from the reaction of either benzeneselenenyl chloride (5) or benzeneseleninyl chloride (6) in near quantitative yield. The diphenyldisulfide and diphenyldiselenide are readily obtained either by recrystallization of the distillation residue of liquid nitriles, or by filtration during the recrystallization of solid nitriles.

In conclusion, it is shown that the very inexpensive, and commercially available technical grade sulfur chlorides $\mathbf{1}, \mathbf{2}$, and $\mathbf{3}$ prove to be very convenient and efficient reagents for the preparation of aromatic nitriles from aldoximes in good yields. Furthermore, the reagents 4,5 , and 6 provide a mild and efficient alternative method for the formation of either aliphatic or aromatic nitriles in good yields. 
Table II. Preparation of nitriles from aldoximes and reagents $\mathbf{3 , 4}, \mathbf{5}$, and $\mathbf{6}$.

\begin{tabular}{|c|c|c|c|c|c|c|c|}
\hline$\underset{\mathrm{R}}{\mathrm{RCH}}=\mathrm{NOH}$ & Reagent & $\begin{array}{l}\text { Yield } \\
{[\%]^{a, b}} \\
\text { of } \\
\text { nitrile }\end{array}$ & $\begin{array}{l}\text { Solventc } \\
\text { reaction } \\
\text { time }[\mathrm{h}]\end{array}$ & $\begin{array}{l}\text { m.p. or } \\
\text { b.p./torr } \\
\text { (Lit. m.p. or } \\
\text { b.p./torr) [12] }\end{array}$ & $\begin{array}{l}n_{\mathrm{D}}^{25} \\
{\left[\text { Lit. } n_{\mathrm{D}}\right.} \\
\text { (temp)] [13] }\end{array}$ & $\begin{array}{l}\text { Molecular } \\
\text { formula }^{\mathrm{d}}\end{array}$ & $\begin{array}{l}\text { Mol. } \\
\text { weight } \\
\text { found }\end{array}$ \\
\hline \multirow[t]{4}{*}{ Phenyl } & 3 & 60 & $\begin{array}{l}\text { Ether } \\
(1.0)\end{array}$ & $69-70^{\circ} / 10$ & $\begin{array}{l}1.5271 \\
{\left[1.5289\left(20^{\circ}\right)\right]}\end{array}$ & $\begin{array}{l}\mathrm{C}_{7} \mathrm{H}_{5} \mathrm{~N} \\
(103.12)\end{array}$ & 100 \\
\hline & 4 & $\begin{array}{l}70 \\
96\end{array}$ & $\begin{array}{l}\text { Ether } \\
(1.0) \\
\text { Chloroform } \\
(1.0)\end{array}$ & $\begin{array}{l}69-70 \% 10 \\
70 \% 10 \\
(69 \% 10)\end{array}$ & $\begin{array}{l}1.5272,1.5274 \\
{\left[1.5289\left(20^{\circ}\right)\right]}\end{array}$ & $\begin{array}{l}\mathrm{C}_{7} \mathrm{H}_{5} \mathrm{~N} \\
(103.12)\end{array}$ & 102,103 \\
\hline & 5 & 86 & $\begin{array}{l}\text { Chloroform } \\
(0.25)\end{array}$ & $\begin{array}{c}70^{\circ} / 11 \\
\left(69^{\circ} / 10\right)\end{array}$ & $\begin{array}{l}1.5273 \\
{\left[1.5289\left(20^{\circ}\right)\right]}\end{array}$ & $\begin{array}{l}\mathrm{C}_{7} \mathrm{H}_{5} \mathrm{~N} \\
(103.12)\end{array}$ & 102 \\
\hline & 6 & 85 & $\begin{array}{l}\text { Chloroform } \\
(0.25)\end{array}$ & $71 \% 12$ & $\begin{array}{l}1.5277 \\
{\left[1.5289\left(20^{\circ}\right)\right]}\end{array}$ & $\begin{array}{l}\mathrm{C}_{7} \mathrm{H}_{5} \mathrm{~N} \\
(103.12)\end{array}$ & 101 \\
\hline \multirow[t]{4}{*}{ 4-Methoxyphenyl } & 3 & 62 & $\begin{array}{l}\text { Ether } \\
(1.0)\end{array}$ & $\begin{array}{c}60-61^{\circ} \\
\left(61-62^{\circ}\right)\end{array}$ & & $\begin{array}{l}\mathrm{C}_{8} \mathrm{H}_{7} \mathrm{NO} \\
(133.15)\end{array}$ & 128 \\
\hline & 4 & 92 & $\begin{array}{l}\text { Chloroform } \\
\text { (1.0) }\end{array}$ & $\begin{array}{c}61-62^{\circ} \\
\left(61-62^{\circ}\right)\end{array}$ & & $\begin{array}{l}\mathrm{C}_{8} \mathrm{H}_{7} \mathrm{NO} \\
(133.15)\end{array}$ & 131 \\
\hline & 5 & 93 & $\begin{array}{l}\text { Chloroform } \\
(0.25)\end{array}$ & $\begin{array}{c}60-61^{\circ} \\
\left(61-62^{\circ}\right)\end{array}$ & & $\begin{array}{l}\mathrm{C}_{8} \mathrm{H}_{7} \mathrm{NO} \\
(133.15)\end{array}$ & 131 \\
\hline & 6 & 88 & $\begin{array}{l}\text { Chloroform } \\
(0.25)\end{array}$ & $\begin{array}{l}61^{\circ} \\
\left(61-62^{\circ}\right)\end{array}$ & & $\begin{array}{l}\mathrm{C}_{8} \mathrm{H}_{7} \mathrm{NO} \\
(133.15)\end{array}$ & 135 \\
\hline \multirow[t]{4}{*}{$n$-Propyl } & 3 & 26 & $\begin{array}{l}\text { Chloroform } \\
\text { (3.0) }\end{array}$ & $\begin{array}{c}117^{\circ} / 750 \\
\left(117^{\circ} / 760\right)\end{array}$ & $\begin{array}{l}1.3848 \\
{\left[1.3842\left(20^{\circ}\right)\right]}\end{array}$ & $\begin{array}{l}\mathrm{C}_{4} \mathrm{H}_{7} \mathrm{~N} \\
(69.11)\end{array}$ & 66 \\
\hline & 4 & 82 & $\begin{array}{l}\text { Chloroform } \\
\text { (3.0) }\end{array}$ & $\begin{array}{c}116^{\circ} / 750 \\
\left(117^{\circ} / 760\right)\end{array}$ & $\begin{array}{l}1.3851 \\
{\left[1.3842\left(20^{\circ}\right)\right]}\end{array}$ & $\begin{array}{l}\mathrm{C}_{4} \mathrm{H}_{7} \mathrm{~N} \\
(69.11)\end{array}$ & 71 \\
\hline & 5 & 77 & $\begin{array}{l}\text { Chloroform } \\
(3.0)\end{array}$ & $116-117^{\circ} / 750$ & $\begin{array}{l}1.3850 \\
{\left[1.3842\left(20^{\circ}\right)\right]}\end{array}$ & $\begin{array}{l}\mathrm{C}_{4} \mathrm{H}_{7} \mathrm{~N} \\
(69.11)\end{array}$ & 70 \\
\hline & 6 & 74 & $\begin{array}{l}\text { Chloroform } \\
(3.0)\end{array}$ & $\begin{array}{c}117^{\circ} / 750 \\
\left(117^{\circ} / 760\right)\end{array}$ & $\begin{array}{l}1.3849 \\
{\left[1.3842\left(20^{\circ}\right)\right]}\end{array}$ & $\begin{array}{l}\mathrm{C}_{4} \mathrm{H}_{7} \mathrm{~N} \\
(69.11)\end{array}$ & 69 \\
\hline \multirow[t]{4}{*}{$n$-Hexyl } & 3 & 30 & $\begin{array}{l}\text { Chloroform } \\
(3.0)\end{array}$ & $\begin{array}{c}66-67^{\circ} / 10 \\
\left(183^{\circ} / 760\right)\end{array}$ & $\begin{array}{l}1.4112 \\
{\left[1.4104\left(30^{\circ}\right)\right]}\end{array}$ & $\begin{array}{l}\mathrm{C}_{7} \mathrm{H}_{13} \mathrm{~N} \\
(111.18)\end{array}$ & 107 \\
\hline & 4 & 80 & $\begin{array}{l}\text { Chloroform } \\
\text { (3.0) }\end{array}$ & $68^{\circ} / 10$ & $\begin{array}{l}1.4109 \\
{\left[1.4104\left(30^{\circ}\right)\right]}\end{array}$ & $\begin{array}{l}\mathrm{C}_{7} \mathrm{H}_{13} \mathrm{~N} \\
(111.18)\end{array}$ & 109 \\
\hline & $\mathbf{5}$ & 83 & $\begin{array}{l}\text { Chloroform } \\
(3.0)\end{array}$ & $\begin{array}{c}67-68^{\circ} / 10 \\
\left(183^{\circ} / 760\right)\end{array}$ & $\begin{array}{l}1.4108 \\
{\left[1.4104\left(30^{\circ}\right)\right]}\end{array}$ & $\begin{array}{l}\mathrm{C}_{7} \mathrm{H}_{13} \mathrm{~N} \\
(111.18)\end{array}$ & 108 \\
\hline & 6 & 81 & $\begin{array}{l}\text { Chloroform } \\
(3.0)\end{array}$ & $\begin{array}{c}67^{\circ} / 10 \\
\left(183^{\circ} / 760\right)\end{array}$ & $\begin{array}{l}1.4109 \\
{\left[1.4104\left(30^{\circ}\right)\right]}\end{array}$ & $\begin{array}{l}\mathrm{C}_{7} \mathrm{H}_{13} \mathrm{~N} \\
(111.18)\end{array}$ & 106 \\
\hline
\end{tabular}

a Yield of pure isolated products.

b The IR and NMR analyses of the products were analogous to those found in Table I.

c Temperature of reaction: $23-35^{\circ} \mathrm{C}$.

d The microanalyses for all aromatic nitriles were in satisfactory agreement with the calculated values $\mathrm{C}, \pm 0.30 ; \mathrm{H}, \pm 0.30 ; \mathrm{N}, \pm 0.30$.

\section{Experimental}

Materials: All reagents were of the finest quality commercially available. The oximes were prepared by standard methods [11]. Diethyl ether was an absolute grade from the Mallinckrodt Company of St. Louis, Missouri. The chloroform was a certified ACS grade from the Fischer Scientific Company of Fair Lawn, New Jersey. The sulfur dichloride was a technical grade from the MC/B Company of Norwood, Ohio. The sulfur monochloride (2), benzeneseleneyl chloride (5), and thiophenol used to produce benzenesulfenyl chloride (4) were obtained from the Aldrich Chemical Co. of Milwaukee, Wisconsin. The trichloromethanesulfenyl chloride (3) was generously supplied by the Stauffer Chemical Co. Benzenesulfenyl chloride (4) was prepared by the reaction of chlorine with thiophenol [9], and was used immediately after distillation. Benzeneseleninyl chloride (6) was prepared by a known method [10].

Analytical procedures: All melting points and boiling points are uncorrected. The IR analyses were recorded on a Perkin-Elmer Infracord Spectrophotometer, Model 137. ${ }^{1} \mathrm{H}$ NMR analyses were 
performed in $\mathrm{CDCl}_{3}$ on a Varian T-60 NMR Spectrophotometer using TMS as an internal standard. Microanalyses for the solid nitriles were obtained on a F \& M Scientific Corporation Carbon, Hydrogen, and Nitrogen Analyzer, Model 185. Molecular weights were determined isopiestically in benzene on a Hitachi Perkin-Elmer Model 115 Molecular Weight apparatus. All conversions of aldoximes to nitriles were followed by thin lay chromatography on pre-coated $0.2 \mathrm{~mm}$ Aluminum Oxide "Polygram", Alox N/uv 254 sheets, Brinkman Instruments, Inc. of Des Plaines, Illinois. A short wave UV lamp was used for the visualization of the spots.

Preparation of nitriles using sulfur dichloride (1) or sulfur monochloride (2)

General procedure: A solution of $\mathbf{1}$, or $2(0.005$ $\mathrm{mol})$, in diethyl ether $(10 \mathrm{ml})$ is added dropwise with stirring, at room temperature in the case of aromatic aldoximes, or at -40 to $-30^{\circ} \mathrm{C}$ in the case of aliphatic aldoximes, to a solution of the aldoxime $(0.010 \mathrm{~mol})$, and triethylamine $(0.010 \mathrm{~mol})$ in diethyl ether $(30 \mathrm{ml})$. The reaction is exothermic. The solution is allowed to come to boil in the case of aromatic aldoximes, or held at $-30^{\circ} \mathrm{C}$ by cooling the reaction vessel in the case of aliphatic aldoximes. The formation of triethylamine hydrochloride is accompanied by the fading of the initial orange coloration of the reaction mixture. The reaction mixture is stirred at either temperature for the prescribed time (Table I), then brought to ambient temperature, and filtered through a diatomaceous earth packing to remove triethylamine hydrochloride and the syrupy yellow sulfur residues. The filter cake is washed with ether $(2 \times 10 \mathrm{ml})$, then the remaining solid is washed with water $(30 \mathrm{ml})$ to dissolve triethylamine hydrochloride, and the aqueous solution is filtered through a diatomaceous earth packing to remove sulfur residues. The aqueous filtrate is concentrated on a rotating evaporator at $23^{\circ} / 10$ torr and the resulting triethylamine hydrochloride crystals are pulverized and dried at $55^{-6}-60^{\circ}$ 40 torr $(97-99 \%$ yield $)$. The combined ethereal solutions are poured into water $(40 \mathrm{ml})$, and the aqueous phase is extracted with ether $(2 \times 10 \mathrm{ml})$. The combined ether extracts are dried over anhydrous magnesium sulfate, then filtered. The filtrate is concentrated on a rotating evaporator at $23-25^{\circ}$ 12-15 torr to give the crude product. The pure nitriles are isolated after a shortpath distillation under reduced pressure (10-15 torr) in the case of liquids, or recrystallization from ethanol/water in the presence of decolorizing carbon, in the case of solids (Table I).

Preparation of nitriles using either trichloromethanesulfenyl chloride (3), benzenesulfenyl chloride (4), benzeneseleneyl chloride (5), or benzeneseleninyl chloride (6)

General procedure: A solution of $\mathbf{3}, \mathbf{4}, \mathbf{5}$, or $\mathbf{6}$ $(0.01 \mathrm{~mol})$, in either ether or chloroform $(20 \mathrm{ml}$,
Table II), is added dropwise with stirring at room temperature under anhydrous conditions to a solution of the aldoxime $(0.01 \mathrm{~mol})$ and triethylamine $(0.01 \mathrm{~mol})$ in ether or chloroform $(30 \mathrm{ml}$, Table II). The reaction is slightly exothermic in the case of 3 . The formation of triethylamine hydrochloride is accompanied by the fading of the initial orange coloration of the reaction mixture. The reaction mixture is stirred at room temperature for the prescribed time (Table II), then filtered through a diatomaceous earth packing to remove triethylamine hydrochloride and the syrupy yellow sulfur residues in the case of 3 . The triethylamine hydrochloride is isolated as described in the preceeding experiment. The filtrate is poured into water $(40$ $\mathrm{ml}$ ), and the aqueous phase is extracted with either ether or benzene $(2 \times 10 \mathrm{ml})$. The combined extracts are dried over magnesium sulfate, then filtered. The filtrate is concentrated on a rotating evaporator at $23-25^{\circ} / 12-15$ torr to give the crude nitrile with reagent 3 or a mixture of nitrile and diphenyldisulfide (7) with reagent 4 or diphenyldiselenide (8) with either reagent 5 or 6 . The crude nitrile thus obtained with reagent 3 is purified by two distillations or recrystallizations as described in the proceding experiment. The pure nitriles from the reactions with 4,5 , and 6 are obtained either by a short-path distillation in the case of liquids, or recrystallization from ethanol/water in the case of solids as described in the preceding experiment. In the case of liquid nitriles, the distillation residue contains the crude disulfide or diselenide. These compounds are purified by recrystallization from water in the presence of decolorizing carbon. In the case of solid nitriles, the disulfide and diselenide are insoluble in the hot ethanol/water recrystallization media, and are collected as crude solids after filtering the hot mixture. The solids are then purified by recrystallization in water in the presence of decolorizing carbon (Table II). The yield of diphenyldisulfide $\left(7, \mathrm{~m} . \mathrm{p} .60-62{ }^{\circ} \mathrm{C}\right.$, lit. [12] 61-62 $\left.{ }^{\circ} \mathrm{C}\right)$ or diphenyldiselenide $\left(8, \mathrm{~m} . \mathrm{p} .63{ }^{\circ} \mathrm{C}\right.$, lit. [12] 63-64 ${ }^{\circ} \mathrm{C}$ ) is $95-98 \%$ of theory based on starting 4,5 , or 6 in all cases.

$7,{ }^{1} \mathrm{H}$ NMR $\left(\mathrm{CDCl}_{3}\right): \delta=7.1-7.35(\mathrm{~m}, 6), 7.40$ to $7.65(\mathrm{~m}, 4)$.

$\mathrm{C}_{12} \mathrm{H}_{10} \mathrm{~S}_{2}$

$$
\text { Calcd C 66.01 H 4.62, }
$$

Found C 66.19 H 4.59.

8, ${ }^{1} \mathrm{H} \mathrm{NMR}\left(\mathrm{CDCl}_{3}\right): \delta=7.2-7.4(\mathrm{~m}, 6), 7.50$ to $7.85(\mathrm{~m}, 4)$.

$$
\begin{array}{ccc}
\mathrm{C}_{12} \mathrm{H}_{10} \mathrm{Se}_{2} & & \\
\text { Calcd } & \mathrm{C} 46.17 & \mathrm{H} 3.23, \\
\text { Found } & \mathrm{C} 46.08 & \text { H } 3.09 .
\end{array}
$$

This investigation was supported by a grant from the Graduate School of the University of Wisconsin-Milwaukee. 
[1] G. Sosnovsky and J. A. Krogh, Synthesis 1978, 703 , and references therein.

[2] G. Sosnovsky and M. Konieczny, Z. Naturforsch. 32 b, 1179 (1977).

[3] M. Konieczny and G. Sosnovsky, Z. Naturforsch. $33 \mathrm{~b}, 1033$ (1978).

[4] F. P. Doyle, W. Ferrier, D. O. Holland, M. D. Mehta, and J. H. C. Nayler, J. Chem. Soc. 1956, 2853.

[5] E. Mueller and B. Narr, Z. Naturforsch. 16 b, 845 (1961).

[6] D. L. J. Clive, Chem. Commun. 1970, 1014.

[7] T. Ho, Synth. Commun. 5, 423 (1975).

[8] J. G. Krause and S. Shaikh, Synthesis 1975, 502.
[9] M. Behforouz and J. E. Kerwood, J. Org. Chem. 34, 51 (1969).

[10] M. R. Czarny, Synth. Commun. 6, 285 (1976).

[11] R. L. Shriner, R. C. Fuson, and D. Y. Curtin, The Systematic Identification of Organic Compounds, 4th Edition, p. 254, John Wiley \& Sons, Inc. New York 1956.

[12] Handbook of Tables for Organic Compound Identification, 3rd Edition, compiled by Z. Rappoport, C. R. C. Press, Inc., Cleveland, Ohio 1967.

[13] Handbook of Chemistry and Physics, 44th Edition, C. D. Hodgman, (ed.), C. R. C. Press, Inc., Cleveland, Ohio 1963. 